\title{
Epistemological Obstacles on The Quadratic Inequality
}

\author{
Kimura Patar Tamba', Melda Jaya Saragih ${ }^{2}$ \\ ${ }^{1,2}$ Pelita Harapan University, Indonesia
}

\begin{tabular}{l} 
Article Info \\
\hline Submitted : $16-07-2020$ \\
Revised : $30-10-2020$ \\
Accepted : $12-11-2020$ \\
Published : 25-11-2020
\end{tabular}

*Correspondence:

kimura89.tamba@gmail.com

\begin{abstract}
Students often experience difficulties and errors in solving quadratic inequality problems. These difficulties and errors are not only caused by students' ignorance or misconceptions, but also caused by epistemological obstacles. This study aimed to determine the epistemological obstacles faced by the junior high school students in quadratic inequality. This research was a qualitative research that involved 105 ninth-grade students at one of the junior high schools in Bandung, Indonesia. The data were collected through open-ended tasks and task-based interviews. The data were analyzed using the inductive coding process to classify students' errors. The descriptive analysis was carried out to reveal students' ways of understanding and ways of thinking behind each error to be compared with historical analysis. Based on the description of ways of understanding and ways of thinking and comparison with this historical phenomenon, the epistemological obstacles had be confirmed. The results showed that there were epistemological obstacles in quadratic inequalities. The epistemological obstacles consisted of students' quadratic equation knowledge acts and students' arithmetic knowledge acts. However, no epistemological obstacles were found in the development history of quadratic inequality. Students' epistemological obstacles were parallel to the historical phenomena of quadratic inequality.
\end{abstract}

Key Words : Epistemological obstacles; Quadratic inequality; Ways of thinking; Ways of understanding.

\section{Introduction}

Quadratic inequality is one of the crucial topics in understanding various topics in mathematics, such as algebra, trigonometry, and analytic geometry (Bicer et al., 2014; Tamba et al., 2018; Tamba \& Siahaan, 2020). The quadratic inequality is deemed essential by the NCTM Curriculum and Curriculum 2013 (in the Indonesian context). Both of these curricula stipulate that junior high school students are expected to explain inequalities by using mathematical symbols and provide interpretations of solutions to these inequalities (Peraturan Menteri Pendidikan Dan Kebudayaan Nomor 21 Tahun 2016 Tentang Standar Isi Pendidikan Dasar Dan Menengah, 2016; NCTM, 2000). In Curriculum 2013, this material was taught to the third-grade students of junior high school.

Various studies show that students experience difficulties in solving quadratic inequality problems (Bicer et al., 2014; Makonye \& Nhlanhla, 2014; Makonye \& Shingirayi, 2014; Tamba et al., 2018; Tamba \& Siahaan, 2020). Bicer (2014) revealed that the preservice teachers experienced difficulties in quadratic inequalities, especially in using inequalities signs, omitting certain values, arithmetic errors, and errors in multiplication and division of negative numbers (misuses of inequalities' rules). Bicer uses a misconception framework to see the source of the error. The findings of research by Blanco \& Garrote (2007) revealed that the two types of difficulties experienced by students are a lack of arithmetic skills or knowledge and the absence of semantic and symbolic meanings of inequalities. Blanco \& Garrote (2007) used the theoretical 
framework of epistemological obstacles as a students' error source. Just like Bicer et al. (2007), Blanco and Garrote's research was not focused on the quadratic inequality.

Research specifically on quadratic inequality was conducted by Mananggel (2020) on high school students. The study found that students' errors in quadratic inequality were errors in reading word problems, errors in language interpretation, errors in understanding the concept of quadratic inequalities, and errors in arithmetic operations (calculation errors). The theoretical framework used in the study has not yet seen the causes behind these errors. The previous research has not used the epistemological obstacles framework to analyze the sources of errors. The study used a procedural, conceptual, and misconception understanding in analyzing the source of errors. The procedural and conceptual understanding framework as a source of students' error is also seen in various other studies on inequality, although not specifically quadratic inequality (Bicer et al., 2014; Blanco \& Garrote, 2007; Makonye \& Nhlanhla, 2014; Makonye \& Shingirayi, 2014).

The previously done studies explored and analyzed students' error sources within the framework of students' ignorance or misconception. Brown (2008) referred this as "a phenomenon of the student" which is a view that sees errors are caused by students' incomplete and incorrect information about the content. Bachelard and Piaget argued that the difficulties faced by students are not just a "phenomenon of the student", but rather caused by srudents' inappropriate and false prior knowledge (Brousseau, 2002). This idea is called learning obstacles. Learning obstacles are not only caused by students' inadequate knowledge, but also caused by incorrect and inappropriate knowledge.

This source of learning obstacles can be divided based on the system of interaction concerning the acquisition of knowledge. Knowledge acquisition occurs in a very complex system of interactions. One of the subsystems consists of teachers, students, and knowledge systems (Brousseau, 2002). Based on this didactic system, didactical obstacles are divided into three forms based on the source of the ontogenic, didactical, and epistemological difficulties. Ontogenic is related to the level of a student's mental development, didactical obstacles are related to the choice of the didactic approach of the teacher, and epistemological obstacles are related to the nature of knowledge (subject matter). Therefore, this research was focused on epistemological obstacles.

Exploration of epistemological obstacles will help teachers design appropriate learning environments. Students learn through interaction over milieu (learning environment). Students use their prior knowledge in interacting with the milieu. For this reason, we need to analyze how prior is an obstacle to the formation of new knowledge. That is, important epistemological obstacles are analyzed and explored to help students construct knowledge through the process of adapting prior knowledge to the milieu. By being aware of and considering epistemological obstacles, the teacher can plan when and how the right way to introduce a concept to students to avoid difficulties that might occur (Tamba et al., 2018; Tamba \& Siahaan, 2020).

\section{Epistemological Obstacles}

Various studies on the quadratic inequality show that the framework used to analyze the source of students' difficulties and errors has not touched the idea of epistemological obstacles. For this reason, this study was focused on epistemological obstacles as a theoretical framework in viewing and analyzing students' difficulties and errors in quadratic inequality. The idea of epistemological obstacles is one of the main theory of didactical situation's ideas (Brousseau, 2002; Tamba \& Siahaan, 2020). According to this theory, knowledge construction is the 
implication of interactions between students and problem situations (broader: milieu); namely, a dialectical interaction where students use prior knowledge to revised, modify, complete, or reject the construction of new knowledge. Students' knowledge was obtained through the adaptation of their way of thinking to a milieu. Therefore, students' errors are caused by the process of adapting the way of thinking and the way of understanding in the milieu (learning environments) (Brousseau, 2002; Sunariah \& Mulyana, 2020; Tamba \& Siahaan, 2020). The theoretical framework of the epistemological obstacles sees that students' source of errors is not merely the knowledge.

The idea of epistemological obstacles was first introduced by Bachelard (Brousseau, 2002; Tamba, 2015) who revealed them in terms of science development. Brousseau (2002) was the first to use this idea in mathematics education. Brousseau changed the perspective of errors or difficulties experienced by students. For him, error is not a result of ignorance or chance, but rather the effect of previously appropriate prior knowledge which now no longer appropriate. Brousseau (2002) defines epistemological obstacles as a form of knowledge that is relevant and appropriate in certain contexts, but in other contexts, that knowledge is wrong and cannot be used. In contrast to didactical obstacles (caused by the learning approach), these obstacles are rooted in the structure of mathematical content itself, in history, and in the development of its application. Examples of epistemological obstacles are revealed by Cornu and Serpinska (Schneider, 2014; Sierpińska, 1987) concerning material limit functions. They proposed a question: "Is the limit attainable or not?." Students experience obstacles because of the understanding that limit values can never be attained (the limit values are never the same as the function values) although it is possible in other contexts. Some limits cannot be attained or approached, for example $\lim _{x \rightarrow \infty} \frac{1}{e^{2}}$. In the other hand, some limits can be attained, for example $\lim _{x \rightarrow 3}(x-1)$. The epistemological obstacles revealed by Cornu and Serpinska show that the obstacles experienced by students are not caused by limited knowledge. Students have prior knowledge that "the value of a limit cannot be achieved". This prior knowledge is appropriate when it is used in $\lim _{x \rightarrow \infty} \frac{1}{e^{2}}$. On the contrary, this knowledge is not appropriate in other contexts, for example $\lim _{x \rightarrow 3}(x-1)$. This is not a misconception because the concept used by students is not wrong in certain contexts. After all, from the students' thought processes, there is no misconception. From a students' perspective, all concepts are based on reasoning, thinking processes, and reasonable conceptions based on their experiences.

\section{Theoretical Framework}

To find out the epistemological obstacles, Brousseau (2002) proposed a method; (1) find repetitive mistakes and affirm that error is knowledge, not ignorance, (2) find obstacles in the history of mathematics, and (3) compare obstacles to history and determine their epistemological character. Finding epistemological obstacles to a mathematical content can be done through historical analysis and analysis of students' ways of knowing.

In this research, the discovery of epistemological obstacles was done by analyzing errors made by students in solving quadratic inequality problems. In this research, the historical analysis was not conducted because historical research itself is a very deep and intensive domain. This research ws focused on the epistemological obstacles experienced by students. Nevertheless, in discussing the results of the research, the students' epistemological obstacles was compared to the historical analyzes of the inequality done by previous researchers. 
The epistemological obstacles had been explored through students' errors in solving mathematical problems, in this case, quadratic inequality. Brousseau (2002) and Tamba (2015) say that epistemological obstacles can be identified through repeated errors made by students. Also, the epistemological obstacles can be identified by looking at the tendency to generalize certain understandings for all situations (Fuadiah, 2015; Prihandhika et al., 2020; Subroto \& Suryadi, 2018).

This generalization tendency occurs because students use their existing ways of knowing in gaining new knowledge (Schneider, 2014). Thus, students' ways of knowing behind the errors in solving mathematical problems needed to be investigated. How are the ways of knowing formed? Siepinska's (Sierpińska, 1987) notion of "property of duality of epistemological obstacles" and dual assertion from Harel (1998) provide answers to the question. Siepinska shows that the ways of knowing are coexisting with students' conceptual understanding related to perspective on certain knowledge. This coexisting concept allows the ways of knowing to be found by looking at students' conceptual understanding that is incompatible with new knowledge. The concept of "property of duality of epistemological obstacles" corresponds to dual assertion from Harel (Lockwood \& Weber, 2015). Dual assertion emphasizes that students' ways of thinking are not the only one that influence the mathematical concepts, but also ways of understanding that influence the ways of thinking (Lockwood \& Weber, 2015). To that end, exploration and discovery of epistemological obstacles of students can be done through analysis on the ways of thinking and ways of knowing in solving mathematical problems. Harel (Lockwood \& Weber, 2015) reveals that ways of understanding are "a particular cognitive product of a mental act carried out by an individual" while the ways of thinking are "a cognitive character of a person, ways of understanding are associated with a particular mental act." For example, in proof, particular proof of a given statement is a way of understanding because it is a product of one instance of mental act of proving. On the other hand, a proof scheme (such as an empirical proof scheme, which includes the belief that showing a statement is true for several examples sufficiently proves the statement) is a way of thinking because it characterizes how a person tends to prove (Lockwood \& Weber, 2015). Therefore, this research explored and described the epistemological obstacles behind students' difficulties and errors in quadratic inequality.

\section{Research Purposes}

This study aimed to determine the epistemological obstacles faced by secondary school students in quadratic inequality by analyzing the types of students' errors. Furthermore, this study also analyzed the ways of thinking and ways of understanding of each student's error. Based on the type of error, ways of thinking, and ways of understanding, the epistemological obstacles in quadratic inequality can be determined. Thus, the research questions of this research were; (1) what are the epistemological obstacles experienced by students in quadratic inequality? (2) what type of errors experienced by students in solving quadratic inequality problem? And (3) what are the ways of thinking and ways of understanding behind the error?

\section{The Research Methods}

This research was an exploratory and descriptive research. Descriptive and exploratory research is research that presents a complete picture of a phenomenon and is intended for exploration and clarification of the phenomenon by describing a number of variables related to the phenomenon (Cohen et al., 2018; Creswell \& Poth, 2018). This research was included into a descriptive reearch because it described the epistemological obstacles based on ways of thinking 
and ways of understanding as sources of errors in solving quadratic inequality. Based on the data collection design, the results are presented in the form of simple statistics related to the classification of errors obtained through an inductive process following the grounded theory approach (Cohen et al., 2018). This research was also an exploratory research because of the scarcity of studies that explore sources of epistemological obstacles from students' errors in solving quadratic inequality.

\section{Study Context}

This research was conducted in the context of didactic design development. In didactic design development, the preliminary study was an analysis of epistemological obstacles that students may experience. This didactic design development uses the Curriculum 2013 framework (Peraturan Menteri Pendidikan Dan Kebudayaan Nomor 21 Tahun 2016 Tentang Standar Isi Pendidikan Dasar Dan Menengah, 2016).

\section{Participant}

This research was conducted on 105 ninth-grade students at one high school in Bandung, Indonesia. The participants were students who had learned the quadratic inequality. This research was a preliminary study of the didactic design development context. Therefore, the participants were selected purposively (those who have received quadratic inequality learning material) by involving all ninth-grade students in the school.

\section{Data Collection}

The data had been collected through survey using questionnaires and task-based interviews. The questionnaire used was an open-ended task. It contained problems regarding quadratic inequality done individually by each participant within 135 minutes. The task-based interviews were semi-structured interviews based on participants' answers to the problem of quadratic inequality. The task-based interviews were conducted based on students' error analysis in solving quadratic inequality problems. All task-based interviews had been recorded and transcribed. The researcher selected three students from each classification of error. The classification of errors consisted of the absence of semantic and symbolic meanings of inequalities, solving inequality in arithmetic, misuses of inequalities' rules, and solution-dependent zero-makers.

\section{Research Instruments}

The instruments used in this research were questionnaires in the form of open-ended tasks and guidelines for task-based interviews. This open-ended task was based on the curriculum 2013 content standards regarding quadratic inequality. There were three problems given to participants that required procedural and conceptual understanding. Specifically, these three problems can be solved by different settlement approaches (such as the sign chart approach, logical connections, and function approaches). The open-ended task was used to see obstacles in the form of ways of knowing in solving the problem of quadratic inequality. The second instrument was an openended task. The task can be seen below:

1. Draw a graph of $y=x^{2}-3 x-4$, then show the graphic image the value of $x$ as a solution to $x^{2}-3 x-4<0$

2. Look at the graph below. Based on the graph, determine the value of $\mathrm{x}$ that satisfies $x^{2}-2 x$ $-3 \geq 0$. 


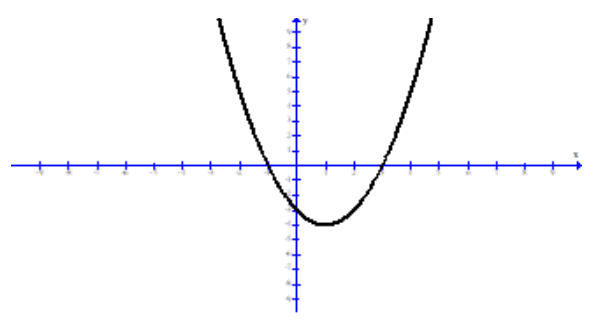

Figure 1. Problem no. 1

3. Determine the set of resolutions from:
a. $(x-3)(x+5)>0$
b. $\quad(x-2)(x+4)<7$
c. $-x^{2}+4 x-3 \geq 0$
d. $\quad 8-2 x-3 x^{2} \leq 0$
e. $x^{2}-4 x+2<0$
f. $x^{2}-2 x+6>0$
g. $-x^{2}+4 x-5 \geq 0$

The open-ended task had been validated by three validators; namely, two mathematics education lecturers and one school teacher. The average validation score showed that the instrument was valid.

The task-based interview guidelines were based on the analysis of students' errors in solving the problem of quadratic inequality in the open-ended task aimed to clarify the interpretation of ways of thinking and ways of understanding.

\section{Data Analysis}

As expressed in the theoretical framework, the epistemological obstacles can be obtained by analyzing students' errors in solving quadratic inequality problems. Thus, this research analyzed other phenomena in students' answers besides errors. To answer the first research question, the researcher analyzed the data by classifying (coding) errors obtained through the inductive process following a grounded theory approach (Cohen et al., 2018). The same pattern and type of errors had been grouped. The resulting data as well as the results of previous studies were used to describe the assumptions about the aspects of ways of thinking and ways of understanding on each type of error.

In this process, the researcher asked one professor and two mathematics education researchers to do a random coding to agree on the general definition of categories and improve the results' reliability. They were also involved in analyzing the descriptive allegations of aspects of ways of thinking and ways of understanding in students' errors. This was done to improve the reliability of the results and the suitability of the error description with the ways of thinking and ways of knowing.

After the process of classification and analysis of descriptive allegations of students' errors had been completed, the task-based interviews were conducted. The interview transcript was then used to clarify, correct, or strengthen the descriptive aspects of ways of thinking and ways of understanding behind the error. The results of interviews on three students for each aspects of ways of thinking and ways of knowing were compared to obtained the final clarification. The results of this process can be seen in Table 1. 


\section{The Results of the Research and the Discussion}

The results of our research had been organized in several stages of analysis. First, the classification of students' errors based on the inductive process following the grounded theory approach was displayed. Second, along with that classification, the ways of thinking and ways of understanding behind each type of errors were analyzed. Third, based on ways of thinking and ways of understanding, the students' epistemological obstacles in quadratic inequality can be described.

\section{Classification of Errors}

After the inductive process following the grounded theory approach had been carried out, the error categorization was obtained as shown in Table 1 . The category was obtained from the classification of students' wrong answers to the task of quadratic inequality. One professor and two mathematics education researchers approved this categorization. The results interpretation had been achieved through a joint critical analysis process supported by researchers' knowledge of previous research regarding quadratic inequality. Based on this process, students' errors were grouped into four types; the absence of semantic and symbolic meanings of inequalities, solving inequality in arithmetic, misuses of inequalities' rules, and solutions depending on the solutiondependent zero-makers.

In the absence of semantic and symbolic meanings of inequalities, the errors were related to students' lack of semantic and symbolic understanding of inequality signs. Students saw the sign as having no semantic meaning apart from connecting two members of the inequality. They solved the quadratic inequality by replacing the "=" sign with the inequality signs " $<$ ", ">", " $\leq$ ", or " $\geq$ ". This was manifested by students' errors in reading signs from left to right and from right to left, such as $-5<x>3$. This was also manifested by the illogical use of these inequality signs in representing the solution of quadratic inequality (see Figure 2). Errors related to the absence of semantic and symbolic meanings of inequalities occurred because of the ways of thinking used by students to make sense of problems (quadratic inequality) as a form of quadratic equations. This means that students simplified the problem of quadratic inequality as a form of quadratic equation problems. This approach allowed them to simply replace the inequality sign with the inequality signs without considering the semantic and symbolic meaning differences. These ways of thinking followed students' ways of understanding that there was no difference in semantic and symbolic meaning between equality and inequality. The results of the interviews reinforced the analysis.

Researcher: How do you read the solution to number 2?

Student: $\mathrm{X}$ is smaller than -1 and greater than 3 .

Researcher: Are there numbers?

Student: These are the ones, so those between -1 and 3 are not included.

Researcher: So this reads " $\mathrm{x}$ is smaller or equal to -1 and greater than 3 . Are there numbers there?

Student: Oh, no. Uh, yes there are, sir. So, those like 0, 1, 2 are not included

Researcher: Yes, but if this one is greater than -1

Student: Smaller than -1 but greater than 3

The above interview shows that students did not understand of the symbolic and semantic meaning of the sign of inequality. In the process, the students found solutions with incorrect meaning. 


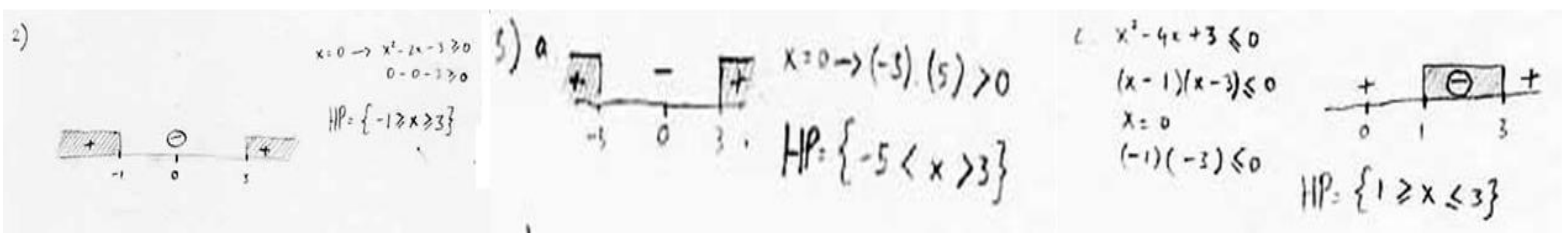

Figure 2. Error as the Absence of Semantic and Symbolic Meanings of Inequalities

The second type of error related to solving inequality in arithmetic. It was related to students' understanding of the variable's domain as the natural numbers and the understanding of quadratic inequalities is only about the selection of the corresponding numbers. Students chose a number, if the number satisfied the inequality, then they put the sign of the inequality according to the sign on the problem. Students assumed that if a certain value had been fulfilled, then a value greater than the value of $\mathrm{x}$ had been met. For the inequality where the sign is smaller or equal to the value of $\mathrm{x}$; thus, it is smaller or equal to $(\leq)$ the value of $x$ (see figure 3 ). Errors related to solving inequality in arithmetic occurred because of students' ways of thinking in the form of arithmetic thinking. The arithmetic thinking was focused on numbers rather than relations, variables, or letters by focusing on focus on number solutions rather than representation.

Table 1. Errors Classification

\begin{tabular}{|c|c|c|c|c|}
\hline $\begin{array}{l}\text { Category } \\
\text { of Errors }\end{array}$ & Errors Description & Ways of Thinking & $\begin{array}{c}\text { Ways of } \\
\text { Understanding }\end{array}$ & Freq \\
\hline $\begin{array}{l}\text { The } \\
\text { absence of } \\
\text { semantic } \\
\text { and } \\
\text { symbolic } \\
\text { meanings of } \\
\text { inequalities }\end{array}$ & $\begin{array}{l}\text { Students incorrectly } \\
\text { used inequality signs. } \\
\text { The use of inequality } \\
\text { signs was not logical, } \\
\text { for example, }-5< \\
x>3 \text {. }\end{array}$ & $\begin{array}{l}\text { Make sense of the } \\
\text { problem (quadratic } \\
\text { inequality) as a } \\
\text { form of quadratic } \\
\text { equations, using the } \\
\text { approach to } \\
\text { quadratic equations } \\
\text { to solve quadratic } \\
\text { inequality problems } \\
\text { by simply replacing } \\
\text { the sign. }\end{array}$ & $\begin{array}{l}\text { There is no } \\
\text { difference in } \\
\text { semantic and } \\
\text { symbolic meaning } \\
\text { between equality } \\
\text { and inequality. }\end{array}$ & $\begin{array}{c}24 \\
(23 \%)\end{array}$ \\
\hline $\begin{array}{l}\text { Solving } \\
\text { inequality } \\
\text { in } \\
\text { arithmetic }\end{array}$ & $\begin{array}{l}\text { Students chose a } \\
\text { number. If the number } \\
\text { satisfied the } \\
\text { inequality, then they } \\
\text { put inequality signs, } \\
\text { for example ( } x- \\
3)(x+3)>0 \text {, } \\
\text { students chose natural } \\
\text { numbers starting from } \\
1 . \text { When } x=4 \text { was } \\
\text { satisfied, they } \\
\text { immediately put } \\
\text { inequality signs; } x \geq \\
4 \text { as a solution. }\end{array}$ & $\begin{array}{l}\text { Arithmetic thinking } \\
\text { (focus on numbers } \\
\text { rather than } \\
\text { relations, variables, } \\
\text { orletters and focus } \\
\text { on number solutions } \\
\text { rather than } \\
\text { representations). }\end{array}$ & $\begin{array}{l}\text { The algebraic form } \\
\text { of a quadratic } \\
\text { inequality is a } \\
\text { general form of } \\
\text { arithmetic } \\
\text { inequality, different } \\
\text { only on the variable } \\
\text { or letter. }\end{array}$ & $\begin{array}{c}95 \\
(91 \%)\end{array}$ \\
\hline $\begin{array}{l}\text { Misuses of } \\
\text { inequalities' } \\
\text { rules }\end{array}$ & $\begin{array}{l}\text { Students incorrectly } \\
\text { used rules in quadratic } \\
\text { inequality }\end{array}$ & $\begin{array}{l}\text { Simplified the } \\
\text { problem of } \\
\text { quadratic inequality } \\
\text { as quadratic }\end{array}$ & $\begin{array}{l}\text { Quadratic } \\
\text { inequality is a } \\
\text { generalization of } \\
\text { quadratic equations }\end{array}$ & $\begin{array}{c}18 \\
(17 \%)\end{array}$ \\
\hline
\end{tabular}




\begin{tabular}{|c|c|c|c|c|}
\hline $\begin{array}{l}\text { Category } \\
\text { of Errors }\end{array}$ & Errors Description & Ways of Thinking & $\begin{array}{c}\text { Ways of } \\
\text { Understanding }\end{array}$ & Freq \\
\hline & & $\begin{array}{l}\text { equations by } \\
\text { replacing the sign }\end{array}$ & $\begin{array}{l}\text { with only sign } \\
\text { differences }\end{array}$ & \\
\hline & $\begin{array}{l}\text { Students incorrectly } \\
\text { understand the } \\
\text { multiplication factor } \\
\text { of a quadratic } \\
\text { inequality }\end{array}$ & $\begin{array}{l}\text { Simplified the } \\
\text { problem of } \\
\text { quadratic inequality } \\
\text { as quadratic } \\
\text { equations by } \\
\text { replacing the sign }\end{array}$ & $\begin{array}{l}\text { Quadratic } \\
\text { inequality is a } \\
\text { generalization of } \\
\text { quadratic equations } \\
\text { with only sign } \\
\text { differences }\end{array}$ & $\begin{array}{c}37 \\
(35 \%)\end{array}$ \\
\hline $\begin{array}{l}\text { Solution- } \\
\text { dependent } \\
\text { zero-makers }\end{array}$ & $\begin{array}{l}\text { Students concluded } \\
\text { that there was no } \\
\text { solution to quadratic } \\
\text { inequality when zero- } \\
\text { maker values did not } \\
\text { exist. Though the } \\
\text { uncertainty has a } \\
\text { solution } \forall x \in R\end{array}$ & $\begin{array}{l}\text { Generalization of } \\
\text { the mathematical } \\
\text { process used in } \\
\text { quadratic equations } \\
\text { in solving a } \\
\text { quadratic inequality }\end{array}$ & $\begin{array}{l}\text { Generalization of } \\
\text { understanding from } \\
\text { quadratic equation } \\
\text { to quadratic } \\
\text { inequality }\end{array}$ & $\begin{array}{c}103 \\
(98 \%)\end{array}$ \\
\hline
\end{tabular}

The results was manifested by the problem-solving approach used by students. The students solved the quadratic inequality by selecting certain natural numbers and then substituting it for inequality. When one value chosen by the student satisfied the quadratic inequality, for example, $x=a$, then they immediately concluded that the solution to quadratic inequality was " $x<a$, " $x>a$ ", " $x \leq a$ " or " $x \geq a$ ". The following interview confirmed this analysis.

Researcher: Next, I want to ask about question number 3. How did you do this? Why were certain values subsidized?

Student: $\quad$ Right, the question asked to find the set of solutions less than 0 , like this $(x-3)(x+5)>0$. I tried the substitution, choose the value of $\mathrm{x}$ whichever fulfilled, until finally, it was not.

Researcher: So, for example, you substituted $x=2$, meaning you followed this sign so $x>2$ ?

Student: $\quad$ Yes, to the extent possible if this [number 3] was not possible.

Researcher: 3 was not possible?

Student: $\quad$ Yes

Researcher: Then, you just made it smaller than 2, right?

Student: Yes, it's the same as the problem [using the same sign as the problem]

Researcher: Oh, the same sign as the problem [sign "="]. Did you answer the others the same way?

Student: Yes sir.

These ways of thinking corresponded to students' ways of understanding who see quadratic inequality as a generalization of arithmetic inequality; thus, there was no difference in principle. The point was that the students saw inequality and equality only in terms of variables or letters, but the principleremained the same. The algebraic form of a quadratic inequality is a general form of arithmetic inequality, differing only by variable or /letter. This can be seen in students' answer to problems no. $3 \mathrm{a}, 3 \mathrm{~b}$, and $3 \mathrm{c}$ (figure 3 ). For example, in question $3 \mathrm{c}$, students saw the problem as merely choosing the correct numbers in quadratic inequality $-x^{2}+4 x-3>0$. The 
answers obtained through these ways of thinking are wrong, limited, and incomplete. After the value of $x=1$ had been substituted and corrected, students immediately concluded the solution $x>1$ (by replacing the sign "=" into a sign "<"). This solution was incorrect because the values of $x>3$ was not a quadratic inequality solution.
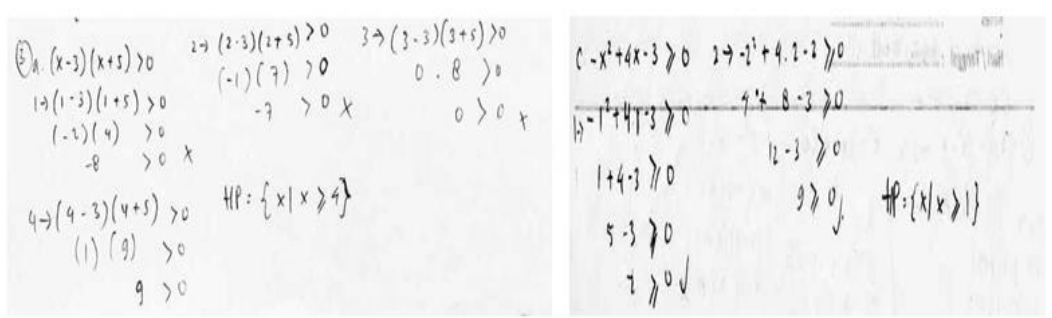

b) $(x-2)(x+4)(7$

\begin{tabular}{|c|}
\hline $\begin{aligned} x: 1 \rightarrow(-1)(3) & =-5 v \\
x: 2 \rightarrow(0)(6) & =0 \\
x: 3 \rightarrow(1)(7) & =7 x\end{aligned}$ \\
\hline
\end{tabular}

\section{Figure 3. Error in Solving Inequality in Arithmetic}

The third type of error was the misuse of inequalities 'rules which related to students' lack of understanding of multiplication and division operations in quadratic inequality. Students multiplied the quadratic inequality with negative numbers without changing the direction of the quadratic inequality sign as can be seen in the answers to problem $3 \mathrm{~d}$ (see figure 4). Students multiplied the inequality of squares with numbers $(-1)$ to change the coefficient of $x^{2}$ to be positive. The goal was to find the factors easier. The students did not change the direction of the quadratic inequality sign.

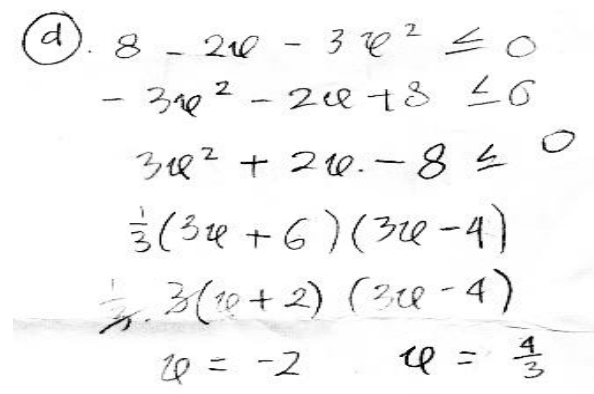

Figure 4. Error in the Misuses of Inequalities' Rules

This third error was related to the generalization of the quadratic inequality; namely in solving problems $(x-5)(x+3) \geq 0$. The students answered: $x \geq 5$ and $x \geq 3$. This solution was obtained by directly using the null value maker and connecting it to the inequality sign. Students who used this method always consistently answer if $(x+a)(x+b) \geq 0$ then $x \geq a$ and $x \geq b$, if $(x+a)(x+b) \leq 0$ then $x \leq 0$ and $b \leq 0$, as well as other equivalent forms. For problems of the form $(x+a)(x+b) \geq 0$ or $(x+a)(x+b)>0$, the answers $x \geq 0$ and $b \geq 0$ or $x \leq 0$ and $b \leq 0$ were correct, but it became wrong when dealing with problems $(x+a)(x+b)<0$.

Ways of thinking behind the types of errors in inequalities' rules are related to ways of thinking that simplify the problem of quadratic inequality as quadratic equations by replacing the sign of inequality into a sign of equality. How to solve this problem is a form of generalization of ways of thinking quadratic equations which is to simplify the form of quadratic equations that have a negative $x^{2}$ coefficient to be positive so that it is easier to get a zero maker without changing the sign " $="$. This happens because students think that inequality and equality require the same mathematical solution process, they treat problems involving inequality in the same way as equations, and assume the problems given require the same process. These ways of thinking correspond to the ways of understanding of students who see that quadratic inequality is a generalization of quadratic equations with only sign differences. This generalization is in the 
form of ways of understanding that multiplication and division will not change the sign of inequality as a sign of equality.

The fourth error was in the form of solution-dependent zero-makers relates to the approach used by students in finding solutions to quadratic inequality. To solve the quadratic inequality, students first changed it to the quadratic equation by replacing the signs "<", ">", " $\leq$ ", or " $\geq$ " to sign " $="$. This change was done by students to get the zero-maker of the quadratic equation. Students concluded that the quadratic inequality did not have a solution when zero-makers cannot be obtained (see figure 5).

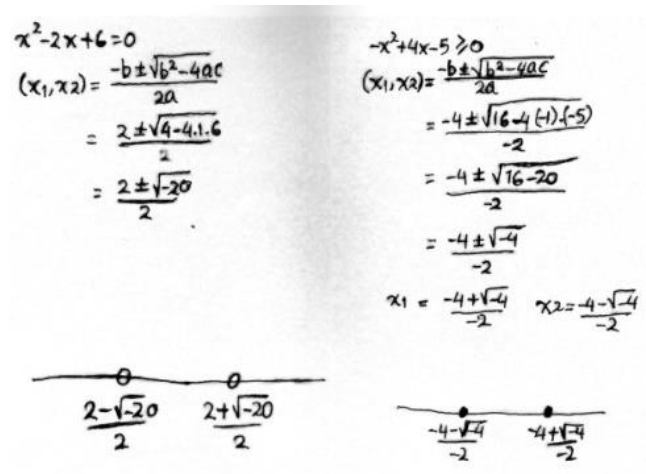

Figure 5. Student's Solution

The way of thinking behind this error was a generalization of the mathematical process used in quadratic equations in solving quadratic inequality. The mathematical process was to determine the zero-maker by factoring the algebraic form of quadratic equations into algebraic factors. The generalized ways of understanding was that the zero-maker determined the solution.

\section{Epistemological Obstacles behind Students' Errors}

From the above analysis, it can be concluded that there were two types of ways of thinking and ways of understanding behind students' errors. The ways of thinking and ways of understanding were (1) generalizing understanding and mathematical processes (thinking) of quadratic equations into quadratic inequalities and (2) generalizing understanding and mathematical processes (arithmetic thinking) to quadratic inequalities (algebra). In other words, students' errors in dealing with quadratic inequality problems occurred because they saw (1) quadratic inequality as quadratic equations and (2) quadratic inequality as generalizations of arithmetic.

Thus, the students' errors were not caused by ignorance; rather, they were caused by the inaccurate knowledge in other contexts, for example, to solve $x^{2}-4 x+3 \leq 0$ students first determined the zero-makers for the equation $x^{2}-4 x+3=0$, i.e. $x=3$ or $x=1$. Based on the zero-makers, students used a sign chart to obtain $1 \leq x \leq 3$ as a solution. These mathematical understanding and processes are problematic when they are generalized into the inequality $x^{2}-$ $2 x+6>0$. In the fourth type of error, students revealed that there was no solution because zeromakers cannot be obtained.

Based on the analysis and discussion, there were two findings in this study. First, students' errors in solving quadratic inequality. Students' errors consisted of the absence of semantic and symbolic meanings of inequalities, solving inequality in arithmetic, misuses of inequalities' rules, and solution-dependent zero-makers. These findings were consistent with several previous research (Bicer et al., 2014; Blanco \& Garrote, 2007; Makonye \& Nhlanhla, 2014; Makonye \& 
Shingirayi, 2014; Mananggel, 2020). Therefore, this study further strengthens previous research regarding students' errors in solving quadratic inequality problems.

Second, the epistemological obstacles behind the errors experienced by students. It was found that the Epistemological obstacles in quadratic inequality are (1) students' quadratic equation knowledge acts and (2) students' arithmetic knowledge acts. Students' quadratic equation knowledge acts indicated that the students see quadratic inequality as a quadratic equation or the generalization of quadratic equations to a quadratic inequality. Students' arithmetic knowledge acts indicated that the students see the quadratic inequality as a form of arithmetic inequality or the generalization of arithmetic knowledge to algebraic inequality (algebra).

These findings are new and have not been disclosed by previous studies. The findings regarding epistemological obstacles on students' errors in solving quadratic inequality are new. Previous studies have not analyzed students' errors from the epistemological aspect (Bicer et al., 2014; Makonye \& Nhlanhla, 2014; Makonye \& Shingirayi, 2014). This research revealed new things that there are epistemological obstacles that cause (reversed) students' errors. Students' errors in solving quadratic inequality occurred because of students' quadratic equation knowledge acts and students' arithmetic knowledge acts. The comparison results with the historical phenomena also contributed to the body of knowledge and research on quadratic inequality. This study revealed the parallelity of historical phenomena with the epistemological obstacles experienced by students.

\section{Conclusion and Suggestion}

Based on the findings and discussion, it can be concluded that there are epistemological obstacles in learning quadratic inequality. These epistemological obstacles relate to students' existing knowledge. Epistemological obstacles in quadratic inequality are (1) students' quadratic equation knowledge acts and (2) students' arithmetic knowledge acts. Students' quadratic equation knowledge acts indicated that the students see quadratic inequality as a quadratic equation or the generalization of quadratic equations to a quadratic inequality. Students' arithmetic knowledge acts indicated that the students see the quadratic inequality as a form of arithmetic inequality or the generalization of arithmetic knowledge to algebraic inequality (algebra).

The knowledge acts see the quadratic inequality solution depends on zero-makers (the concept of quadratic equations). Students revealed that the quadratic inequality has no solution if the zero-makers do not exist. In certain contexts (e.g. $x^{2}-3 x+2>0$ ), these ways of understanding and ways of thinking are appropriate. In other contexts (e.g. $x^{2}-3 x+4>0$ ), these ways of thinking and ways of understanding will cause errors.

This study was limitated to understand and explore the epistemological obstacles behind the students' errors. The dual assertions framework allows us to know the ways of thinking and ways of understanding behind errors. However, very often, what students express is a form of concept image in their answers. This concept image is different from the formal aspect. The epistemological obstacles can be seen if there is a difference between the concept image and the formal aspect; thus, causing an error. Therefore, there needs to be further research using a different framework, for example, the praxeology approach. The findings with dual assertions framework can be deepen if the praxeological approach analysis is used. For that further research, 
it is necessary to analyze the epistemological obstacles in quadratic inequality using other frameworks, such as the praxeology approach.

\section{References}

Bicer, A., Capraro, R. M., \& Capraro, M. M. (2014). Pre-service teacher's linear and quadratic inequality understanding. International Online Journal of Educational Science, 3(3), 221229.

Blanco, L. J., \& Garrote, M. (2007). Difficulties in learning inequalities in students of the first year of pre-university education in Spain. Eurasia Journal of Mathematics, Science and Technology Education, 3(3), 221-229. https://doi.org/10.12973/ejmste/75401

Brousseau, G. (2002). Theory of Didactical Situations in Mathematics. In Theory of Didactical Situations in Mathematics. Kluwer Academic Publishers. https://doi.org/10.1007/0-30647211-2

Brown, S. A. (2008). Exploring epistemological obstacles to the development of mathematics induction. The 11th Conference for Research on Undergraduate Mathematics Education, $1-19$.

Cohen, L., Manion, L., \& Morrison, K. (2018). Research Methods in Education (8th ed.). Routledge.

Creswell, J. W., \& Poth, C. N. (2018). Qualitative inquiry \& research design: Choosing among five approaches. In $S A G E$ (4th ed.). SAGE.

Fuadiah, N. F. (2015). Epistemological Obstacles on Mathematic'S Learning in Junior High School Students: a Study on the Operations of Integer Material. May, 17-19. https://eprints.uny.ac.id/23197/1/ME - 43.pdf

Peraturan Menteri Pendidikan Dan Kebudayaan Nomor 21 Tahun 2016 Tentang Standar Isi Pendidikan Dasar Dan Menengah, 3345 (2016).

Lockwood, E., \& Weber, E. (2015). Ways of Thinking and Mathematical Practices. The Mathematics Teacher, 108(6), 461. https://doi.org/10.5951/mathteacher.108.6.0461

Makonye, J., \& Nhlanhla, S. (2014). Exploring 'non-science' grade 11 learners' errors in solving quadratic equations. Mediterranean Journal of Social Sciences, 5(27), 634-644. https://doi.org/10.5901/mjss.2014.v5n27p634

Makonye, J., \& Shingirayi, M. (2014). The Obstacles Faced by the Learners in the Learning of Quadratic Inequalities. Mediterranean Journal of Social Sciences, 5(27), 716-725. https://doi.org/10.5901/mjss.2014.v5n27p716

Mananggel, M. B. (2020). Diagnosing Students' Difficulties in Solving Mathematical Word Problem. JUPITEK: Jurnal Pendidikan Matematika, 2(2), 61-68. https://doi.org/10.30598/jupitekvol2iss2pp61-68

NCTM. (2000). Principles and Standard for School Mathematics. he National Council of Mathematics of Teacher of Mathematics Inc.

Prihandhika, A., Prabawanto, S., Turmudi, T., \& Suryadi, D. (2020). Epistemological Obstacles: An Overview of Thinking Process on Derivative Concepts by APOS Theory and Clinical Interview. Journal of Physics: Conference Series, 1521(3). https://doi.org/10.1088/1742$6596 / 1521 / 3 / 032028$ 
Schneider, M. (2014). Epistemological Obstacles in Mathematics Education (S. Lerman (ed.); Vol. 52, Issue 1). Springer. https://doi.org/10.1007/s11858-020-01130-4

Sierpińska, A. (1987). Humanities students and epistemological obstacles related to limits. Educational Studies in Mathematics, 18(4), 371-397. https://doi.org/10.1007/BF00240986

Subroto, T., \& Suryadi, D. (2018). Epistemological obstacles in mathematical abstraction on abstract algebra. Journal of Physics: Conference Series, 1132(1). https://doi.org/10.1088/1742-6596/1132/1/012032

Sunariah, L., \& Mulyana, E. (2020). The didactical and epistemological obstacles on the topic of geometry transformation. Journal of Physics: Conference Series, 1521(3). https://doi.org/10.1088/1742-6596/1521/3/032089

Tamba, K. P. (2015). Pengembangan Desain Didaktis Pertidaksamaan Kuadrat pada Sekolah Menengah Atas. Universitas Pendidikan Indonesia.

Tamba, K. P., Saragih, M. J., \& Listiani, T. (2018). Learning Trajectory of Quadratic Inequality. JOHME: Journal of Holistic Mathematics Education, 2(1), 12. https://doi.org/10.19166/johme.v2i1.1202

Tamba, K. P., \& Siahaan, M. M. L. (2020). Pembuat Nol sebagai Hambatan Didaktis dalam Pertidaksamaan Kuadrat. JNPM (Jurnal Nasional Pendidikan Matematika), 4(2), 292. https://doi.org/10.33603/jnpm.v4i2.3614 